\title{
Injecting Green Innovation Reporting into Sustainability Reporting
}

Parvez Alam Khan ${ }^{1}$, Satirenjit Kaur Johl Pritam Singh ${ }^{1}$, Shireenjit Kaur Johl ${ }^{2}$, Amjad Shamim ${ }^{1}$, Yadi Nurhayadi $^{3}$, N.Wijiharjono ${ }^{3}$, and Ummu S. Al-Azizah

\author{
${ }^{1}$ Department of Management and Humanities, Universiti Teknologi, PETRONAS \\ ${ }^{2}$ Department of Accounting, Finance and Economics, Griffith University \\ ${ }^{3}$ Faculty of Economics and Business -University of Muhammadiyah Prof Dr HAMKA (UHAMKA)
}

Corresponding Author

satire@utp.edu.my

\section{Abstract}

Reporting is a method for businesses to communicate with their various stakeholders. While the factors contributing to sustainability reporting and disclosure have been thoroughly investigated, the findings are inconclusive. Similarly, the non-financial reporting literature is disclosed of operational and nonoperational activities related to ecological as well as social disclosure of firm. However, in recent years, stakeholders have increased their demand for green innovation practices (GIPs) to be included as a new component of ecological reporting. Thus, companies' proactivity in adopting green innovation reporting is reflected (GIR). This research propounds enhancing transparency in sustainability reporting by including corporations' GIPs, which will increase the transparency level of firm operations and instil greater stakeholder confidence. To accomplish this study, the legitimacy and signalling theories were used as an environmental solution.

Additionally, an exhaustive assessment of the literature was conducted in order to develop a GIR framework for enterprises to use when integrating GIPs into sustainability reporting. The outcome of this study indicates that current sustainability reporting takes a minimalist approach, with GIR being presented superficially. This non-financial reporting approach does not accurately reflect a company's genuine GIPs or the environmental effect of existing business operations. As such, this study calls for the integration of GIR into firms' sustainability reporting to accurately reflect their actual firm sustainable practices.

Keyword: Integrating Reporting, Green Innovation Reporting, Sustainable Reporting

\section{Introduction}

The increased understanding and concern for the ecological and society in business activity and the impact of social and environmental (Jan, Lai et al. 2021) (Jan, Lai et al. 2021) has heightened senior management's desire to manage their firm and social impacts actively. Numerous authors (Toha, Johl et al. 2020, Johl and Toha 2021, Pichlak and Szromek 2021, Wang, Li et al. 2021, Yilmaz 2021) conducted research on environmental disclosure and reporting (Hamad, Draz et al. 2020), establishing connections between firm ownership, size (Aldieri and Vinci 2019, Phoprachak and Buntornwon 2020), corporate governance characteristics (Siregar and Utama 2008), and other related issues. Additionally, over the last few decades, rising interest and attention in the reporting process, as well as stakeholder demand, have pushed corporations to disclose the firm operations in their annual and sustainable report.

Further, integrated reporting (IR) is viewed as a critical method for developing and strengthening relationships between stakeholders and the organization. Integrated reporting has provided businesses with five significant benefits, the first of which is risk management. (Ruiz 2020), fostering shareholder confidence (Khan, Johl et al. 2021), encouraging long-term investment, ensuring transparency, and 
streamlining operations. Similarly, including environmental, social, and governance (ESG) factors into corporate reporting has aided in forecasting and achieving strong revenue growth.

Diverse viewpoints on sustainable reporting have been investigated concerning the role of top leadership (Bing and Amran, 2017), females in leadership positions (Furlotti, Mazza, Tibiletti and Triani, 2019), reporting on sustainability in family-owned businesses (Gavana, Gottardo and Moisello, 2016), the board of directors' responsibilities (Ebben, Sieswerda et al. 2020) ISO 14001, ISO 9000 (Ali and Johl 2021) regarding the relationship between gender diversity and ESG reporting (Ismail and Latiff 2019).

However, there is very little research on reporting on green innovation activities (GIR). To increase the firm's innovativeness and transparency, the green innovation reporting can act as an enhancer and will result in a rise in the level of trust amongst the organization and its stakeholders. Green innovation is defined as environmentally friendly innovation that reduces greenhouse gas emissions, waste, and energy consumption while increasing the efficiency and effectiveness of manufacturing processes, services, and technologies. This research adheres to the same concept of GIR as it pertains to the reporting of green products, processes, services, and technology (Chen, 2008).

Green products, processes, services, and technology all contribute to a company's operational and financial performance. Similarly, their reporting will increase the transparency of business activities (Chen, 2008). In the lens of transparency around the company, activities contribute to the development and establishment of confidence between stakeholders and the sustainable firm in this aspect.

As a result, this study contributes more insight into enhancing the reporting capability of green innovation activities (GIPs), assisting businesses in becoming more proactive in planning, organizing, and managing their operations. In other words, progress toward GIR will aid businesses in achieving sustainability goals and establishing a competitive edge over competitors.

In addition, the effect of green innovation reporting is asses by the accounting ratios, which gives the effect of practices on the company's balance sheet; the accounting ratio financial parameter is being widely accepted in the various major field of business such as banking (Akhtar, Khan et al. 2020), sustainable reporting(Cordova, Zorio-Grima et al. 2021), and corporate governance(Shwairef, Amran et al. 2021), however, this study is not measuring the performance of firm on the incorporation of green innovation reporting in integrating reporting. This study is advocating to enhance the quality discloser and innovation discloser in the integrating reporting.

This paper is divided into many sections that discuss the preceding literature in this topic, the development of the GIR framework, and the context for GIR adoption.

\section{Prior Literature and Framework Development}

In recent decades, the boom in green innovation literature has been noticed in Scopus and web of science database with academics and scholars examining the factors and drivers of sustainable disclosure from various viewpoints, including economics, engagement, risk management, and environmental management and social interaction with the underlying theories.

There are a variety of theories that are regularly referenced to support the arguments in the literature. For example, Incorporated disclosure theory emphasizes the promotion and use of environmental disclosure in corporate reporting, which is considered to be a positive aspect in the economic success of organizations. Second, Legitimacy theory encourages and supports the voluntary disclosure of social and environmental facts to meet the standards set by national laws and legislation.

Thirdly, according to institutional theory, countries are passive recipients of pressure at several institutional levels. However, blue-chip firms are essential in shaping laws and public perceptions of businesses' economic, social, and environmental responsibilities. Finally, stakeholder theory promotes engagement with stakeholder expectations and obligations, therefore increasing sustainability. 
Nonetheless, there is another theory, the agency theory; although the current study relies on the signalling and legitimacy theories to bolster its argument, the legitimacy theory is used, as this study recommends the establishment of reporting criteria. In contrast, The signalling theory hypothesis is used to advocate for voluntary reporting, and the disclosure of a business's green innovativeness in its sustainability reporting.

\subsection{Variables of Green Innovation and Reporting}

Over the last few decades, environmental reporting has been intensively examined. Most firms reveal their business operations in terms of greenhouse gas emissions, waste creation, water consumption, biodiversity, and other key environmental and social consequences. Similarly, Green innovation has pushed for the modification or introduction of new industrial processes, systems, and technology that can further reduce harmful emissions and pollutants, therefore contributing to a greener, more sustainable environment (Khan and Johl., 2019).

According to Chen (2006), firms gain a green core competence and goodwill as a result of green innovation. This research not only calls for voluntary disclosure of green innovation and its impact on the environment and society, but also for voluntary disclosure of the costs and benefits of green innovation, also for reporting on green innovation aspects such as products, processes, services, and technology that are employed in the course of a business's operational and contribute to the business's a green core competence, green goodwill, and green creativeness.

\subsubsection{Green Product Innovation and Reporting (GPIR)}

GPI has bestowed numerous benefits amongst the stakeholders during the innovation lifecycle. However, the development of the green product is indolent in coinciding with future expectations, as (Ilg 2019) stated. Green product innovation emboldens the economic and productive use of defined resources, and it depreciates the waste to generate added earnings and fund flows (Khan, Johl et al. 2021, Rehman, Kraus et al. 2021).

Green product innovation also creates green goodwill, builds a unique market position, gains a competing advantage, and builds a green leadership reputation. It turns into an immense benefit hotspot for organizations and ready to make altruism in the customer's brains. Furthermore, (Ar 2012) indicates that if the business focuses on innovating product and product environmental repercussions, it will gain the upper hand over its rivals.

Moreover, the firm's green product can create a unique position in the market and create green goodwill in the stakeholder's eye. The green production innovation also shows the improvised production process, generating more revenue and lowering the cost without increasing the burden on environmental challenges. Large GPI also intends to mitigate global warming and other ecological challenges (khan et al., 2019).

Since the mid of the industrial revolution third, the literature on environmental innovation has been evolving. In the fourth industrial revolution, the GPI literature has established a unique position in the market to create a competitive edge, instil green governance goodwill, and incorporate green governance. Additionally, it is also seen favourably by internal and external stakeholders, encouraging long-term investment.

On the other side, company activity reporting is the way to retain the investors and attract the stakeholders in the long run. Therefore, this study propounds to incorporate the reporting variable into the 
GPI. Also, this study argues that GPIR will increase product transparency in a firm annual report, therefore improving operational reporting and assisting shareholders' interests in concluding. These decisions may contribute to the growth of long-term investments and the development of the company's financial statement.

\subsubsection{Green Process Innovation Reporting (GprocIR)}

Debate on the growing phenomenon of process innovation in the corporation is the emergence of inductive thinking and creative design thinking, including new eco-friendly technology, green human resources, and green work practices to construct the structured approach to innovating the green production process. This can help the organization maximize operation capability and focus on customer value, mitigating the production and working environment risk.

GPI is the second critical component of green innovation which focuses on mitigating harmful environmental impacts through waste control, water management, and sustainable raw material procurement. (Khan, Kaur et al. 2021) (Khan and Johl 2019). Additionally, it improves organizational performance and reduces the organization's operating costs (Liu, Li et al. 2020), allowing for revenue generation (Karabulut and Hatipoğlu 2020) and the development of trust among internal stakeholders (Khan and Johl 2020). This is because GPI eliminates the firm incidents, thus providing a secure workplace for its workers. It also benefits companies in terms of revenue and draws external stakeholders' attention to their firm's performance.

Additionally, green process innovation improves the organization's operational efficiency and financial performance and contributes to developing trust amongst internal stakeholders (Khan et al. 2019). However, it remains debatable if green process innovation has any influence on a firm's financial success. Moreover, the research generally agrees on improving the company's processes and minimizing environmental and social impacts. According to (Bhatia 2021, Khan, Kaur et al. 2021, Wang, Li et al. 2021), Green process innovation improves employee safety by minimizing adverse effects inside the business, such as water contamination, toxic waste, and pollutants. The major industry has internal environmental safety, such as oil and gas companies (Ali, Dominic et al. 2020) and other most polluting industries.

Nonetheless, the reporting of actual business operations continues to be a source of contention in the literature on sustainable reporting. To contribute to the growing body of sustainable literature, this study pulls together different research domains, including green process innovation and reporting, and incorporates new components into reporting, particularly green process innovation reporting. (GprocIR). Indeed, it is a new aspect of operational reporting. A business may reveal the impact of innovation on the green process over the environment and on the business production process.

Therefore, GIR promotes and reports on green technology, water and recycling and reuse, energy usage, product recalls, and staff procedure retraining, disposal, and certifications.

\subsubsection{Green Service Innovation Reporting (GSIR)}

Green service innovation is the third imperative variable. It has drawn the attention of academia and industry due to the demand for competitiveness and under-researched variable of green innovation. (Chang 2018).GSI is less scrutinized by the environmental regulators (Khan and Johl 2019). Furthermore, green service innovation can also be the source of minimizing the firm's cost of capital, reducing costs(Zhang, $\mathrm{Xu}$ et al. 2020) from the green service innovation and incorporating the environmental perspective, which can make the firm stand out among its competitors 
Additionally, GSI should not be seen just as a cost-cutting measure or as a driver for reducing the environmental effect. However, GSI assesses every aspect of green innovation has the potential to contribute equally to reaching economic, social, and sustainable development goals. To achieve GSI, Chen, Lin, Lin, \& Chang (2015) mentioned that a firm's absorptive capacity and dynamic capacities must be green, and GSI must have a positive association with firm success. However, GSI literature has contributed another disputed aspect, stating that green dynamic capacities increase GSI and that green competitive edge is positively related to green dynamical capabilities.

This study considers all the positive effects of GSI and adds a new reporting element in GSI. GSIR is described as the innovative reporting of green services, which may help organizations increase their operational transparency. Furthermore, GSIR may be quantified by an audit of green services, the lifecycle of replacing products, the recycling or disposal of replacement product parts, and the use of green technologies in service provision.

\section{Green Technology Innovation Reporting (GTIR)}

In the current industrial revolution, where advancements in advanced technology are being presented daily, researchers Sun, Miao, \& Yang (2017) conducted the study on green technology innovation to address climate change, reduce greenhouse gas emissions, reduction of waste, and conserve water, the literature indicates that government monitoring agencies are mostly absent from corporate renewable technology adoption.

Green technology is an environmentally friendly technology that businesses can improvise their goods, operations, and services to achieve long-term sustainability. Here, Guo, Xia, Zhang \& Zhang (2018) demonstrate that environmental rules have a large U-shaped relationship with green technology innovation, government financing, and incentives in terms of tax relief to encourage the adoption of GTI for energy efficiency and emission reduction. On the other hand, GTI reporting is an essential part of GIR and applies to operational activities (Schiederig, Tietze and Herstatt, 2012). Business operational activities are evaluated and assessed regularly by investors while making investment decisions and are reported using a minimalist manner.

Therefore, Green technological innovation reporting (GTIR) improves environmental disclosure quality and transparency in reports on sustainable practices. Lastly, GTIR can be quantified by the initial implementation of renewable technology, the generation of waste, and energy consumption.

\section{Early Adoption of Green Innovation Reporting}

Globally, acceptance and implementation of ESG and operational reporting have aided in increasing the legitimacy of businesses' operations. The research on ESG and operational reporting has demonstrated several favourable benefits on company operating performance, including reduced environmental impact and increase in performance. Similarly, this research implies the incorporation of GIR into firms' sustainability reporting. The early adoption of GIR will enable the distinction between an organization's sustainability as a business and its sustainability reporting. Implementing the new GIR will further strengthen the company's measuring criteria (Key Performance Indicators), communication, cooperation, firm growth, and sustainable practices, all of which will create a competitive edge and contribute bottom line.

Despite the fact that GIR is optional reporting, the initial implementation will show the company's realtime innovativeness, which will enhance operational reporting. Likewise, operational reporting may be quantified using the same four criteria as operational reporting: green goods, green processes, green 
services, and green technology. This research adopts the four crucial criteria in developing the GIR framework model.

\section{Green Innovation Reporting Framework Model}

The purpose of the new proposed GIR framework model, which incorporates the voluntary disclosure and legitimacy theories, is to build relationships between the variables. The green innovation reporting is supported through voluntary disclosure theory and legitimacy theory to develop relationships with the environmental, social aspects and voluntary disclosure

The research framework model has the green innovation variable and voluntary discloser as the dependent variable as presented in figure

Figure.1: Green Innovation Reporting Model

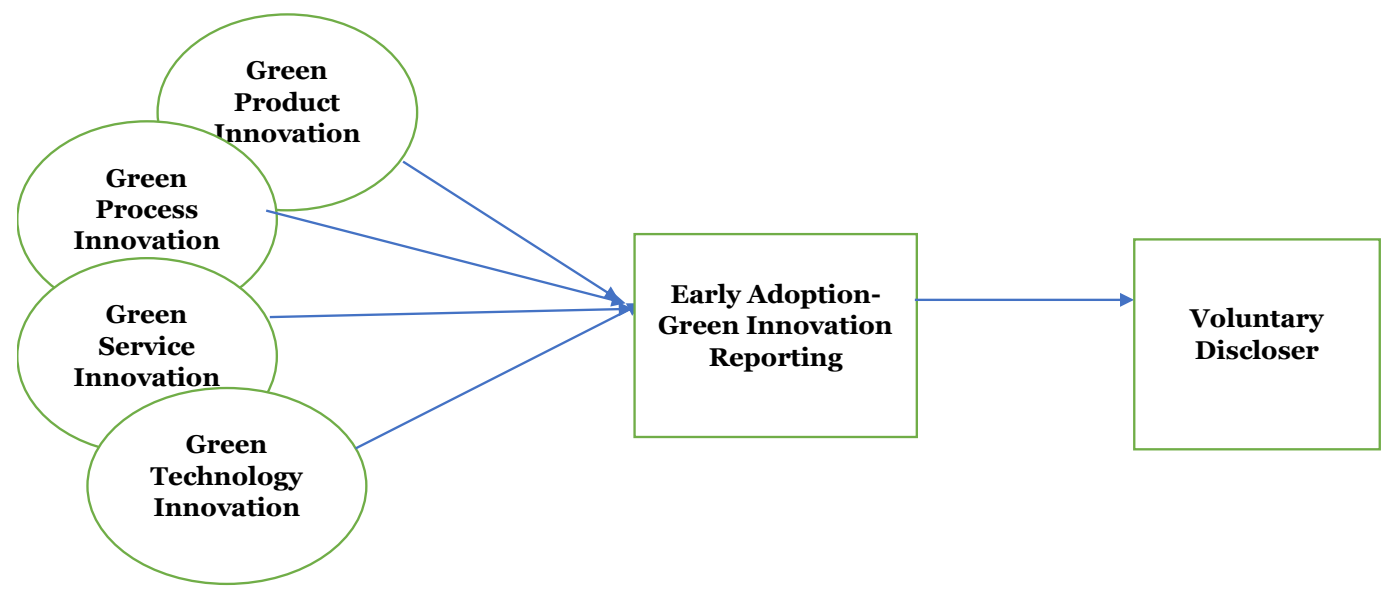

The projected green innovation reporting model is expected to bridge the gap of innovation practices and reporting, establish communication with sustainable, responsible investors and stakeholders, and improve business innovation initiatives' transparency.

The first mover of GIR will provide businesses with a competitive advantage in the short run and generate investment opportunities in the long run. The green innovation reporting highlights the newness of the firm's products, processes, services, and technology. As a result, real-time GIR will improve the firm's reporting quality and capabilities, allowing stakeholders to assess the firm's performance on a new GIR metric in addition to operational and non-operational reporting.

This study thoroughly evaluated relevant literature on green innovation to quantify GIR variables, as shown in Table: 1 .

Table 1: Literature Peer-Reviewed

\begin{tabular}{|l|l|}
\hline Reference & Measurement of Green Innovation Reporting \\
\hline & Green Product Innovation Reporting \\
\hline & Green Product Innovation Goal \\
\hline
\end{tabular}




\begin{tabular}{|c|c|}
\hline $\begin{array}{l}\text { (Duque-Grisales, Aguilera-Caracuel et al.) (Palčič and Prester } \\
\text { 2020), (Toha, Johl et al. 2020) }\end{array}$ & ISO 14001 Certification \\
\hline \multirow[t]{2}{*}{ (Das, Yedlarajiah et al. 2000) (Das and Naik 2002) } & Disassembly and Disposal \\
\hline & Eco-Labelling \\
\hline (Das, Yedlarajiah et al. 2000) & Lifecycle effect on the environment \\
\hline (Alhadid and As' ad 2014) & Continues Improvement /Innovation \\
\hline (Santoso and Fitriani 2016) & Green Packaging \\
\hline (Khan and Johl 2019) & Emission Intensity (Per product) improvement \\
\hline (Khan and Johl 2019) & Product buyback \\
\hline \multirow[t]{12}{*}{ (Khan, Johl et al. 2021) } & Green Process Innovation Reporting \\
\hline & Employee process training (Environment) \\
\hline & Green Technology \\
\hline & Emission reduction \\
\hline & Water consumption Minimization \\
\hline & Recycle \\
\hline & Waste generation Minimization \\
\hline & Recycle \\
\hline & Disposal \\
\hline & Energy Minimisation \\
\hline & Renewable energy Consumption bowzer 1 \\
\hline & ISO 56002-2019 \\
\hline \multirow[t]{4}{*}{ (Khan, Johl et al. 2021) } & Green Service Innovation Reporting \\
\hline & Green Service \\
\hline & Internal Green service auditing \\
\hline & Green Technology Innovation Reporting \\
\hline (Du, Li et al. 2019) & The innovation of Clean Technology \\
\hline \multirow[t]{2}{*}{ (Du, Li et al. 2019) } & Adoption of Clean Technology \\
\hline & Collaboration for Clean Technology \\
\hline
\end{tabular}

\section{Conclusion}

Reporting is regarded as an effective means of communication between businesses and their stakeholders. Furthermore, the reporting and disclosure of business operations show the firms' normative approach to sustainable policies and performance by attaining the policymakers' recommended standards. However, there is an increasing need to combine GIR and stakeholders' green strategies, paving the way for a new method and element of environmental reporting. Furthermore, this will represent companies' proactiveness in implementing GIR. 
The major goal of this research was to see if company GIPs might be used as a catalyst for the disclosure of sustainable reporting, which would improve the quality of business activity reporting. This study revealed the gaps in this domain through a review of earlier literature and the support of numerous theories in bridging these gaps, such as the legitimacy theory and proactive therapy theory. An intensive literature assessment also aided in developing the GIR framework model, which must be included in company sustainability reports.

The expected findings of this research will reveal the possibility of the integration of green innovation reporting with environmental reporting utilizing a minimalist approach, according to this study, where GIR is now reported superficially. Furthermore, due to existing business practices, this reporting approach fails to reflect its genuine green innovativeness and impact on the environment. Therefore, as a result, this study recommends that GIR be incorporated into corporate sustainability reporting to reflect the company's actual sustainable innovation strategies.

Finally, this research demonstrates to the United Nations 17 Sustainable Development Goals management team that green innovation practices and reporting are a means of implementing the SDGs at the company level, as demonstrated by this research's findings.

\section{Future Research}

Future research could empirically explore, examine, and validate the proposed framework model as described in this study in different industry sectors and economies, based on the work and findings of this study. This study also invites further research to broaden the framework's application in early new GIR features in corporate sustainability reporting.

Funding: This study is funded from the matching fund of U.T.P. Malaysia and Uhamka Indonesia (Grant No: 015ME0-174)

\section{Acknowledgement}

The authors like to express their appreciation to the MH Department at Universiti Teknologi Petronas in Malaysia for assisting in this study.

\section{Reference}

1. Bing, N. S., \& Amran, A. (2017). The Role of Board Diversity on Materiality Disclosure in Sustainability Reporting. Global Business and Management Research, 9(4s), 96-109.

2. Chen, J., Yin, X., \& Mei, L. (2018). Holistic innovation: an emerging innovation paradigm. International Journal of Innovation Studies, 2(1), 1-13.

3. Chen, Y. S., Lin, Y. H., Lin, C. Y., \& Chang, C. W. (2015). Enhancing green absorptive capacity, green dynamic capacities and green service innovation to improve firm performance: An analysis of structural equation modeling (SEM). Sustainability, 7(11), 15674-15692.

4. Chen, Y. S., Lai, S. B., \& Wen, C. T. (2006). The influence of green innovation performance on corporate advantage in Taiwan. Journal of business ethics, 67(4), 331-339.

5. Chen, Y. S. (2008). The driver of green innovation and green image-green core competence. Journal of business ethics, 81(3), 531543.

6. Furlotti, K., Mazza, T., Tibiletti, V., \& Triani, S. (2019). Women in top positions on boards of directors: Gender policies disclosed in Italian sustainability reporting. Corporate Social Responsibility and Environmental Management, 26(1), 57-70.

7. García-Sánchez, I. M., Suárez-Fernández, O., \& Martínez-Ferrero, J. (2019). Female directors and impression management in sustainability reporting. International Business Review, 28(2), 359-374.

8. Guo, Y., Xia, X., Zhang, S., \& Zhang, D. (2018). Environmental regulation, government R\&D funding and green technology innovation: evidence from China provincial data. Sustainability, 10(4), 940.

9. Gavana, G., Gottardo, P., \& Moisello, A. M. (2017). Sustainability reporting in family firms: A panel data analysis. Sustainability, 9(1), 38 .

10. Hall, J., Matos, S., \& Bachor, V. (2019). From green technology development to green innovation: inducing regulatory adoption of pathogen detection technology for sustainable forestry. Small Business Economics, 52(4), 877-889. 
11. Ismail, A. M., \& Latiff, I. H. M. (2019). Board Diversity and Corporate Sustainability Practices: Evidence on Environmental, Social and Governance (ESG) Reporting. International Journal of Financial Research, 10(3).

12. Khan, P. A., \& Johl, S. K. (2019). Nexus of Comprehensive Green Innovation, Environmental Management System-14001-2015 and Firm Performance. Cogent Business \& Management, 6(1), 1691833.

13. Masud, M. A. K., Nurunnabi, M., \& Bae, S. M. (2018). The effects of corporate governance on environmental sustainability reporting: Empirical evidence from South Asian countries. Asian Journal of Sustainability and Social Responsibility, 3(1), 3.

14. Ma, Y., Hou, G., \& Xin, B. (2017). Green process innovation and innovation benefit: The mediating effect of firm image. Sustainability, 9(10), 1778.

15. Schiederig, T., Tietze, F., \& Herstatt, C. (2012). Green innovation in technology and innovation management-an exploratory literature review. R\&d Management, 42(2), 180-192.

16. Sun, L. Y., Miao, C. L., \& Yang, L. (2017). Ecological-economic efficiency evaluation of green technology innovation in strategic emerging industries based on entropy weighted TOPSIS method. Ecological Indicators, 73, 554-558.

17. Xie, X., Huo, J., \& Zou, H. (2019). Green process innovation, green product innovation, and corporate financial performance: A content analysis method. Journal of Business Research, 101, 697-706.

18. Xie, X., Huo, J., Qi, G., \& Zhu, K. X. (2015). Green process innovation and financial performance in emerging economies: Moderating effects of absorptive capacity and green subsidies. IEEE Transactions on Engineering Management, 63(1), 101-112.

19. Akhtar, S., et al. (2020). "EXAMINE THE KEY DRIVERS AFFECTING BOTTOM LINE: A PANEL ESTIMATION STUDY OF INDIAN COMMERCIAL BANK." Journal of Critical Reviews 7(9): 2020.

20. Aldieri, L. and C. P. Vinci (2019). "Firm Size and Sustainable Innovation: A Theoretical and Empirical Analysis." Sustainability 11(10).

21. Alhadid, A. Y. and H. A.-R. As' ad (2014). "The Impact of green innovation on organizational performance, environmental management behavior as a moderate variable: An analytical study on Nuqul group in Jordan." International Journal of Business and Management 9(7): 51.

22. Ali, K. and S. K. Johl (2021). Impact of Total Quality Management on SMEs Sustainable Performance in the Context of Industry 4.0. International Conference on Emerging Technologies and Intelligent Systems, Springer.

23. Ar, I. M. (2012). "The impact of green product innovation on firm performance and competitive capability: the moderating role of managerial environmental concern." Procedia-Social and Behavioral Sciences 62: 854-864.

24. Bhatia, M. S. (2021). "Green process innovation and operational performance: The role of proactive environment strategy, technological capabilities, and organizational learning." Business Strategy and the Environment.

25. Chang, C. H. (2018). "How to Enhance Green Service and Green Product Innovation Performance? The Roles of Inward and Outward Capabilities." Corporate Social Responsibility

26. Environmental Management 25(4): 411-425.

27. Cordova, C., et al. (2021). "Contextual and corporate governance effects on carbon accounting and carbon performance in emerging economies." Corporate Governance: The International Journal of Business in Society.

28. Das, S. K. and S. Naik (2002). "Process planning for product disassembly." International Journal of Production Research 40(6): $1335-1355$.

29. Das, S. K., et al. (2000). "An approach for estimating the end-of-life product disassembly effort and cost." International Journal of Production Research 38(3): 657-673.

30. Du, K., et al. (2019). "Do green technology innovations contribute to carbon dioxide emission reduction? Empirical evidence from patent data." Technological Forecasting and Social Change 146: 297-303.

31. Duque-Grisales, E., et al. "Does green innovation affect the financial performance of Multilatinas? The moderating role of ISO 14001 and R\&D investment." Business Strategy and the Environment.

32. Ebben, K. C., et al. (2020). "Impact on Quality of Documentation and Workload of the Introduction of a National Information Standard for Tumor Board Reporting." JCO Clinical Cancer Informatics 4: 346-356.

33. Hamad, S., et al. (2020). "The impact of corporate governance and sustainability reporting on integrated reporting: A conceptual framework." SAGE Open 10(2): 2158244020927431.

34. Ilg, P. (2019). "How to foster green product innovation in an inert sector." Journal of Innovation \& Knowledge 4(2): 129-138.

35. Ismail, A. M. and I. H. M. Latiff (2019). "Board Diversity and Corporate Sustainability Practices: Evidence on Environmental, Social and Governance (ESG) Reporting." International Journal of Financial Research 10(3).

36. Jan, A. A., et al. (2021). "Integrating sustainability practices into islamic corporate governance for sustainable firm performance: from the lens of agency and stakeholder theories." Quality \& Quantity: 1-24.

37. Jan, A. A., et al. (2021). "Developing an Islamic Corporate Governance framework to examine sustainability performance in Islamic Banks and Financial Institutions." Journal of Cleaner Production 315: 128099.

38. Johl, S. K. and M. A. Toha (2021). "The Nexus between Proactive Eco-Innovation and Firm Financial Performance: A Circular Economy Perspective." Sustainability 13(11): 6253.

39. Karabulut, T. and H. N. Hatipoğlu (2020). "The Effect of Green Product Innovation and Green Process Innovation on Company Performance." International Journal of Commerce and Finance 6(1): 181-193.

40. Khan, P. A. and S. K. Johl (2019). "Nexus of Comprehensive Green Innovation, Environmental Management System-14001-2015 and Firm Performance." Cogent Business \& Management 6(1).

41. Khan, P. A. and S. K. Johl (2020). "Firm Performance from the Lens of Comprehensive Green Innovation and Environmental Management System ISO." 
42. Khan, P. A., et al. (2021). "Does adoption of ISO 56002-2019 and green innovation reporting enhance the firm sustainable development goal performance? An emerging paradigm." Business Strategy and the Environment.

43. Khan, S. J., et al. (2021). "Green process innovation: Where we are and where we are going." Business Strategy and the Environment.

44. Liu, H., et al. (2020). "An Empirical Study on the Impact of Environmental Tax and Government Innovation Subsidy on Enterprise Green Process Innovation."

45. Palčič, I. and J. Prester (2020). "Impact of Advanced Manufacturing Technologies on Green Innovation." Sustainability 12(8): 3499.

46. Phoprachak, D. and T. Buntornwon (2020). Influence of Firm Size on the Environmental Disclosure and Performance of the Listed Companies on the Stock Exchange of Thailand. Responsible Business in a Changing World, Springer: 159-170.

47. Pichlak, M. and A. R. Szromek (2021). "Eco-Innovation, Sustainability and Business Model Innovation by Open Innovation Dynamics." Journal of Open Innovation: Technology, Market, and Complexity 7(2): 149.

48. Rehman, S. U., et al. (2021). "Analyzing the relationship between green innovation and environmental performance in large manufacturing firms." Technological Forecasting and Social Change 163: 120481.

49. Ruiz, M. (2020). Governance, Risk Management, Reporting, and Control at the Central Bank of Colombia. Asset Management at Central Banks and Monetary Authorities, Springer: 335-346.

50. Santoso, I. and R. Fitriani (2016). "Green packaging, green product, green advertising, persepsi, dan minat beli konsumen." Jurnal Ilmu Keluarga \& Konsumen 9(2): 147-158.

51. Shwairef, A., et al. (2021). "The mediating effect of strategic posture on corporate governance and environmental reporting." Review of Managerial Science 15(2): 349-378.

52. Siregar, S. V. and S. Utama (2008). "Type of earnings management and the effect of ownership structure, firm size, and corporategovernance practices: Evidence from Indonesia." The international journal of accounting 43(1): 1-27.

53. Toha, M., et al. (2020). "Firm's Sustainability and Societal Development from the Lens of Fishbone Eco-Innovation: A Moderating Role of ISO 14001-2015 Environmental Management System." Processes 8(9): 1152.

54. Toha, M. A., et al. (2020). "Firm's Sustainability and Societal Development from the Lens of Fishbone Eco-Innovation: A Moderating Role of ISO 14001-2015 Environmental Management System." Processes 8(9): 1152.

55. Wang, M., et al. (2021). "Green process innovation, green product innovation and its economic performance improvement paths: A survey and structural model." Journal of Environmental Management 297: 113282.

56. Yilmaz, I. (2021). "Sustainability and financial performance relationship: international evidence." World Journal of Entrepreneurship, Management and Sustainable Development.

57. Zhang, W., et al. (2020). "How green transformational leadership affects green creativity: Creative process engagement as intermediary bond and green innovation strategy as boundary spanner." Sustainability 12(9): 3841. 